\section{Avaliação da continuidade de uso do preservativo feminino em usuárias do Sistema Único de Saúde em unidades da região metropolitana de São Paulo, Brasil*}

\section{Evaluation of continuity of use of female condoms among users of the Brazilian National Health System (SUS): longitudinal analysis in units in the metropolitan region of São Paulo, Brazil}

\section{Suzana Kalckmann'}

Norma Farias"

\section{José da Rocha Carvalheiro'}

' Instituto de Saúde da Secretaria de Estado da Saúde de São Paulo.

" Departamento de Epidemiologia da Faculdade de Saúde Pública da USP.

* Thesis presented to the Sciences Graduate Program of the Coordenadoria de Controle de Doenças da Secretaria de Estado da Saúde de São Paulo, to attain the title of PhD in Sciences. Major: Infectious Diseases in Public Health, in 2007.

Supervisor: Prof. Dr. José da Rocha Carvalheiro, Co-supervisor: Prof. Dr. Norma Farias

Correspondência: Suzana Kalckmann. Instituto de Saúde. Rua Santo Antonio, 590, 3ํandar. São

Paulo, SP. CEP:01314-000. E-mail: suzanak@isaude.sp.gov.br

\section{Resumo}

O perfil da epidemia da Aids vem exigindo alternativas que, além de prevenir a entrada do HIV, facilitem a negociação de uso com o parceiro e possibilitem dupla proteção - contra as infecções transmitidas sexualmente, inclusive a Aids, e contra a gravidez não desejada - como o preservativo feminino.

O objetivo do presente estudo foi verificar se a alta aceitabilidade inicial do preservativo feminino, descrita em outros estudos, é mantida na rotina de atendimento às diferentes populações vulneráveis. Foram monitorados durante 12 meses 16 serviços do Sistema Único de Saúde da Grande São Paulo (7 serviços especializados em atendimento às doenças sexualmente transmissíveis, 6 unidades básicas de saúde e 3 projetos comunitários). Foram incluídas no estudo 2.469 mulheres, das quais $713 \mathrm{em}$ serviços de atenção especializada às DST/ Aids, 1.417 em unidades básicas e 339 em projetos comunitários.

A análise da continuidade de uso foi realizada por tábua de sobrevida KaplanMeier, teste log-rank e modelo de regressão de Cox, com intervalo de confiança de 95\% (IC=95\%). Observou-se que, ao final do seguimento, estavam em uso contínuo do preservativo feminino $14,4 \%$ das mulheres (355). O tempo médio de uso foi de 3,55 meses (IC 95\%: 3,37- 3,73).

Os resultados evidenciaram que o tipo de serviço de dispensação do insumo e a frequência mensal de relações sexuais interferiram na continuidade de uso de forma estatisticamente significante.

O número de mulheres que iniciaram o uso do preservativo feminino nos diferentes tipos de serviços mostrou que há uma demanda para alternativas de prevenção, e que é fundamental a criação de espaços onde elas possam ter acesso adequado a orientações e aos insumos.

Palavras-chave: Preservativo feminino. Preservativos. Prevenção de Aids. Estudo longitudinal. Avaliação em saúde. 


\section{Abstract}

The new profile of the AIDS epidemic necessarily includes the implementation of alternatives which go beyond HIV prevention, meaning sexual partner negotiation and double protection: against STD (including AIDS) and unplanned pregnancy - the female condom (FC) as a possible alternative.

The objective of this study was to assess continuity of the high initial acceptability of FC described in different studies. Vulnerable groups were monitored for 12 months: 16 public services of the São Paulo metropolitan area (7 specialized in STD/AIDS; 6 primary care units and 3 community projects). 2,469 women were enrolled, 713 from STD/ AIDS services, 1,417 from primary care units and 339 from community projects.

Kaplan-Meier, log-rank and the Cox regression model were used to analyze survival curves, $\mathrm{CI}=95 \%$. At the end of followup, 355 (14.4\%) women were using female condom continuously. The mean period of use of all participants was 3.55 months (CI 95\%: 3.37- 3.73)

Results showed type of service providing the device and frequency of sexual intercourse as factors statistically significant related to continuity of use. The high number of women accepting the use of female condom in different services showed an important demand for the device, the need to provide appropriate access to orientation and of making female condom continuously available.

Key words: female condom, condom, Aids prevention, follow-up studies.

\section{Introduction}

In Brazil, the proportional increase in AIDS cases through heterosexual transmission has been faster than other routes among adults with 13 years and over. This growth has been accompanied by expressive participation of women in the epidemiological profile of the disease, observed through progressive reduction in the sex ratio, in all transmission categories, from 26.5, in 1985, to 1.8 , in 1999 and to 1.4 in $2005^{1,2}$.

Despite the contribution of anatomical and physiological characteristics of women to their higher vulnerability, several authors have referred that socioeconomic factors are more striking, and explain more appropriately the current picture of the epidemic, especially in poor and developing countries ${ }^{3}$. The asymmetrical relations established between men and women are revealed through sexual violence, commercial sex, inter-generational sex, and in the greater difficulty in negotiating the adoption of safer sexual practices, which evidently increase the vulnerability of women to STD and, especially, to HIV. Despite the differences among countries and peoples, it should be said that there are frequent synergic interactions in gender, race/ ethnicity, social class and age $\mathrm{e}^{4,5}$.

There have been worldwide efforts to develop and adopt new alternatives for double protection in order to face the situation: avoid unwanted pregnancy and STDs / HIV, contributing to the "empowerment" of women. In this scenario, as of 1993, studies on female condom throughout the world, including Brazil, have been encouraged ${ }^{6,7,8}$.

International and domestic studies, despite different methodological approaches and the diversity of the populations investigated, indicate that it is a feasible method, with immediate acceptability, ranging from $37 \%$ to $96 \%{ }^{6,7}$ It is worth pointing out that observation period was below 90 days, and therefore there were no answers on continuity of use and adherence in the medium and/or long term-fundamental issues for defining the dispensation method by the public network. 
In Brazil, the female condom was introduced in the market after receiving a trade license from the Ministry of Health, in December 1997.

The present study aims to assess acceptability (time of continuous use) in the medium and long term by users of Unified Health System services, in the Greater São Paulo region, during service routine, identifying associated factors.

\section{Method}

The present study used data from the operational Project to introduce female condom in the state of São Paulo, which took over the responsibility for training professionals, making input available, preparing monitoring tools and providing technical support for developing the activity in selected health services ${ }^{9}$.

The present study used a longitudinal design to assess the effectiveness of using the method, defined by WHO as the expression of the desired effect of a program, service or activity to improve a health status or reduce a problem, in actual care conditions ${ }^{10}$. An intervention strategy (use of female condom) with follow-up of women was adopted in order to perform the assessment.

In practical terms, implementation of interventions in public health of the nature mentioned above is not "totally experimental", as it corresponds to an also volunteer process, within a context of interest by decision makers, professionals and users, and that generally coincides with the development of technologies ${ }^{11}$.

The choice of carrying out a study in actual routine service conditions, without adding external elements, such as interviewers or economic aid for transportation and meals, enhances the possibility of continuing the activity investigated after the end of data collecting.

It is therefore an investigation on the introduction of innovation in a service that may be incorporated to routine if feasibility is demonstrated.

Sixteen method dispensation units that committed to continuing the project and incorporating the monitoring tool to the dispensation routine of female condom for at least 12 months were selected and included in the study. There were seven services specialized in STD/AIDS; six primary care units and three community associations. Of the primary care units, two belonged to the Family Health Program (Programa de Saúde da Família - PSF), three were Health Centers linked to Universities and one was a Municipal Primary Health Care Unit with community health agents (PACS). Community associations that develop special prevention programs in self-help housing projects, under the supervision of the State STD/AIDS Program, were considered as community project units for the purpose of the present study.

All women who accepted to take part in the study and wanted to try the female condom, from January 2000 to July 2002, and who could be followed for at least 12 months were included from each unit selected.

The monitoring form, added/incorporated to the medical file, was filled out by services professionals. Service follow-up was carried out through bimonthly visits, with monitoring and (digital) completion of database. Fieldwork began in January 2000 and ended in July 2003. The input, male and female condoms, was guaranteed throughout the study. There was at least one key or reference individual for the activity at all units.

The dependent variable (response analyzed) was the period of use of female condom, collected at each user's follow-up visit to the service, when the date and quotas of female and male condoms taken and used during the period were registered. The assumption was that a woman who returned to the service to get a new quota was using the female condom.

Events were considered as final outcomes when the user: stated she did not want to continue using female condom; did not return to the service and, therefore, would not have the method available anymore, and in cases in which the period between 
follow-up visits was above 45 days.

The independent variables related to individual features were collected upon the volunteer joining the study, selected based on literature review, and agreed upon with services: age, schooling, having a sexual partner or not, living with a partner or not, number of sexual relations in the past month, having a paid activity, color, contraceptive method in use, previous use of male condom, previous use of female condom and having had an STD in the past year. The type of service was also considered as an independent variable for analysis.

The analysis of continuity of use was performed using Kaplan-Meier survival, logrank test and the Cox regression model, and respective $95 \%$ confidence intervals $(\mathrm{CI})^{12}$.

The initial time (time zero) considered was the date in which the method was taken for the first time with intention of use.

Only the variables that had already presented statistical significance $(p<0.05)$ in the Kaplan-Meier analysis were used to build the Cox regression model. Data were analyzed in the SPSS version 12 computer program.

The study was submitted to Instituto de Saúde Ethics in Research Committee and approved to be carried out in January 2000.

\section{Results}

\section{Sample}

The study included 2,469 women, of which 713 (28.9\%) from the seven specialized STD/AIDS care units, 1,417 (57.4\%) from the six primary care units and 339 (13.7\%) from the three community project units.

Table 1 presents the socio-demographic and behavioral characteristics of the population studied, according to the type of condom dispensation service.

Women from 14 to 69 years of age took part, with a mean age of 30.6 years $( \pm 8.98$ years) and median of 29.5 years. There were 47 women $(1.9 \%)$ over 50 years and 112 (4.5\%) below 18 years.

Women of different levels of schooling wanted to try the female condom, including 51 women $(2.1 \%)$ who had never been to school and 99 (4.0\%) women who had complete college education. Women who stopped studying at any grade of "primary school", without having concluded it, were considered of "low schooling". "High schooling" included those that referred to at least having completed "primary" school ( $1^{\text {st }}$ to $9^{\text {th }}$ grade).

Most women (56.9\%) had had some kind of paid activity in the month previous to the interview.

Among all participants, most (91.8\%) had a stable partner, $73.8 \%$ of which lived together, with similar proportions between the different types of services.

Major variability was observed in the frequency of sexual intercourse, from zero to 201 times a month, with a mean of 9.7 times/month $( \pm 9.4$ times $)$, median of 8 times/month and mode of four times/ month. Among the total, 76 women (3.1\%) stated not having had sexual intercourse in the month previous to the interview, and 9 stated having had over 84 . Those who had not had sexual intercourse were kept in the analysis because they stated the intention of having it. Those with more than 84 were excluded from mean and median calculation, as they were outlier values.

The mean of times of sexual intercourse among women in community project units was observed to be higher (12.5 times/month), and the lowest was in (8.1 times/month) specialized services, that totaled the highest number of those who did not have sexual intercourse in the period. At primary health care units the mean was 9.8 times/month.

Adopting some contraceptive practice upon entry in the study was reported by $86.0 \%$ of participants. Practices were grouped as: "low efficacy" (coitus interruptus (withdrawal) and calendar-based methods), "male condom", "hormone", and "high efficacy" (IUD, tubal ligation, vasectomy and those that stated not in risk of pregnancy).

Practically all of them (92\%) had already used male condoms, at least once, previously. 
Tabela 1 - Distribuição das participantes segundo variáveis selecionadas por tipos de serviço de dispensação do preservativo feminino, 2008.

Table 1 - Distribution of participants according to selected variables, in relation to type of facility providing female condoms, 2008.

\begin{tabular}{|c|c|c|c|c|c|c|c|c|c|}
\hline \multirow[t]{3}{*}{ Variables selected } & & \multicolumn{6}{|c|}{ Type of dispensing facility } & \multirow{2}{*}{\multicolumn{2}{|c|}{ Total }} \\
\hline & & \multicolumn{2}{|c|}{ Specialized care } & \multicolumn{2}{|c|}{ Basic Units } & \multicolumn{2}{|c|}{ Community projects } & & \\
\hline & & $\mathrm{N}$ & $\%$ & $\mathrm{~N}$ & $\%$ & $\mathrm{~N}$ & $\%$ & $\mathrm{~N}$ & $\%$ \\
\hline \multicolumn{10}{|l|}{ Age } \\
\hline Groups & Up to 30 years & 295 & 42.6 & 851 & 60.4 & 163 & 48.9 & 1309 & 53.7 \\
\hline (years) & 30 or more & 398 & 57.4 & 559 & 39.6 & 170 & 51.1 & 1127 & 46.3 \\
\hline Total & & 693 & 100.0 & 1410 & 100.0 & 333 & 100.0 & 2436 & 100.0 \\
\hline \multirow[t]{3}{*}{ Schooling } & None & 16 & 2.3 & 26 & 1.9 & 9 & 2.7 & 51 & 2.1 \\
\hline & Low & 344 & 50.1 & 617 & 44.4 & 184 & 55.4 & 1145 & 47.5 \\
\hline & High & 327 & 47.6 & 748 & 53.8 & 139 & 41.9 & 1214 & 50.4 \\
\hline$\underline{\text { Total }}$ & & 687 & 100.0 & 1391 & 100.0 & 332 & 100.0 & 2410 & 100.0 \\
\hline Paid & Yes & 376 & 55.5 & 863 & 62.3 & 105 & 35.2 & 1344 & 56.9 \\
\hline work & No & 301 & 44.5 & 522 & 37.7 & 193 & 64.8 & 1016 & 43.1 \\
\hline Total & & 677 & 100.0 & 1385 & 100.0 & 298 & 100.0 & 2360 & 100.0 \\
\hline Having a steady & Yes & 631 & 92.4 & 1280 & 91.2 & 309 & 93.4 & 2220 & 91.8 \\
\hline partner & No & 52 & 7.6 & 123 & 8.8 & 22 & 6.6 & 197 & 8.2 \\
\hline Total & & 683 & 100.0 & 1403 & 100.0 & 331 & 100.0 & 2417 & 100.0 \\
\hline Living with & Yes & 471 & 74.6 & 910 & 71.1 & 257 & 83.4 & 1638 & 73.8 \\
\hline partner & No & 160 & 25.4 & 370 & 28.9 & 51 & 16.6 & 581 & 26.2 \\
\hline Total & & 631 & 100.0 & 1280 & 100.0 & 308 & 100.0 & 2219 & 100.0 \\
\hline Number of sexual & Up to 4 & 278 & 43.8 & 457 & 33.9 & 69 & 21.1 & 804 & 34.8 \\
\hline Intercourses & 4 to 10 & 208 & 32.8 & 456 & 33.9 & 95 & 29.1 & 759 & 32.9 \\
\hline / month & Above 10 & 149 & 23.5 & 434 & 32.2 & 163 & 49.8 & 746 & 32.3 \\
\hline Total & & 635 & 100.0 & 1347 & 100.0 & 327 & 100.0 & 2309 & 100.0 \\
\hline \multirow[t]{4}{*}{ Contraceptive practice } & Little effective & 14 & 2.1 & 77 & 5.5 & 12 & 3.6 & 103 & 4.3 \\
\hline & Highly effective & 155 & 23.9 & 360 & 25.7 & 77 & 23.3 & 592 & 24.6 \\
\hline & Hormone & 58 & 8.6 & 398 & 28.4 & 103 & 31.2 & 559 & 23.2 \\
\hline & Male condom & 447 & 66.3 & 566 & 40.4 & 138 & 41.8 & 1151 & 47.9 \\
\hline$\underline{\text { Total }}$ & & 674 & 100.0 & 1401 & 100.0 & 330 & 100.0 & 2405 & 100.0 \\
\hline \multicolumn{10}{|l|}{ Previous } \\
\hline use of male & Yes & 670 & 98.2 & 1252 & 89.9 & 292 & 88.0 & 2214 & 92.0 \\
\hline condom & No & 12 & 1.8 & 140 & 10.1 & 40 & 12.0 & 192 & 8.0 \\
\hline Total & & 682 & 100.0 & 1392 & 100.0 & 332 & 100.0 & 2406 & 100.0 \\
\hline \multicolumn{10}{|l|}{ Previous } \\
\hline use of male & Yes & 76 & 11.1 & 92 & 6.6 & 29 & 8.7 & 197 & 8.2 \\
\hline condom & No & 607 & 88.9 & 1308 & 93.4 & 303 & 91.3 & 2218 & 91.8 \\
\hline Total & & 683 & 100.0 & 1400 & 100.0 & 332 & 100.0 & 2415 & 100.0 \\
\hline \multirow[t]{5}{*}{ Self reported color } & White & 323 & 50.1 & 678 & 48.8 & 120 & 36.1 & 1121 & 47.4 \\
\hline & Black & 80 & 12.4 & 165 & 11.9 & 35 & 10.5 & 280 & 11.8 \\
\hline & Brown & 234 & 36.3 & 529 & 38.1 & 173 & 52.1 & 936 & 39.6 \\
\hline & Yellow & 8 & 1.2 & 14 & 1.0 & 4 & 1.2 & 26 & 1.1 \\
\hline & Indian & & - & 2 & 0.1 & - & - & 2 & 0.1 \\
\hline Total & & 645 & 100.0 & 1388 & 100.0 & 332 & 100.0 & 2365 & 100.0 \\
\hline
\end{tabular}


The female condom was new for most (91.8\%), regardless of type of service.

The majority self defined themselves as white $(47.4 \%)$, although when "black" encompassed those self defined as "negro" and "brown", the group became majority, $51.4 \%$ of total.

\section{Continuity of use}

At the end of 12 months of observation, $14.4 \%$ (355) of women continued using the female condom. On the third month of follow-up the proportion was $36.5 \%$ (901), and on the sixth month, about 180 days, it became $27.3 \%$ (673).

The highest interruption of use in the first follow-up was evident, corresponding to one month after receiving condoms, period in which $46.3 \%$ of participants $(1,142)$ discontinued the method (Figure 1).

The mean time of use was 3.55 months (CI 95\%: 3.37-3.73)

Survival analysis by the Kaplan-Meier method showed statistically significant association between period of continuity of use of female condom and schooling
( $\mathrm{p}=0.035)$, paid work $(\mathrm{p}<0.001)$, living with a partner $(\mathrm{p}=0.003)$, color $(\mathrm{p}<0.001)$, number of times having intercourse per month $(\mathrm{p}<0.001)$ and type of service $(\mathrm{p}<0.001)$, (Figure 2)

The highest proportion of use at the endpoint was among those who had not been to school, and the lowest with "high" schooling (13.4\%); among those with "low" schooling it was $15.8 \%(\mathrm{p}=0.035)$.

Higher adherence was observed among those who did not have a paid activity (18.7\%) than among those who did $(\mathrm{p}<0.001)$.

The highest likelihood of use in the 12th month was observed among those who lived with their partners (16.4\%) than among the others $(\mathrm{p}=0.003)$.

Considering self referred color, longer period of use was observed in "black" (17.9\%) individuals than among white ones $(\mathrm{p}<0.001)$.

In the Cox regression multivariate analysis, only the variables "monthly sexual frequency" and "type of service" remained statistically significant (table 2), showing that:

Women who had 11 or more sexual con-

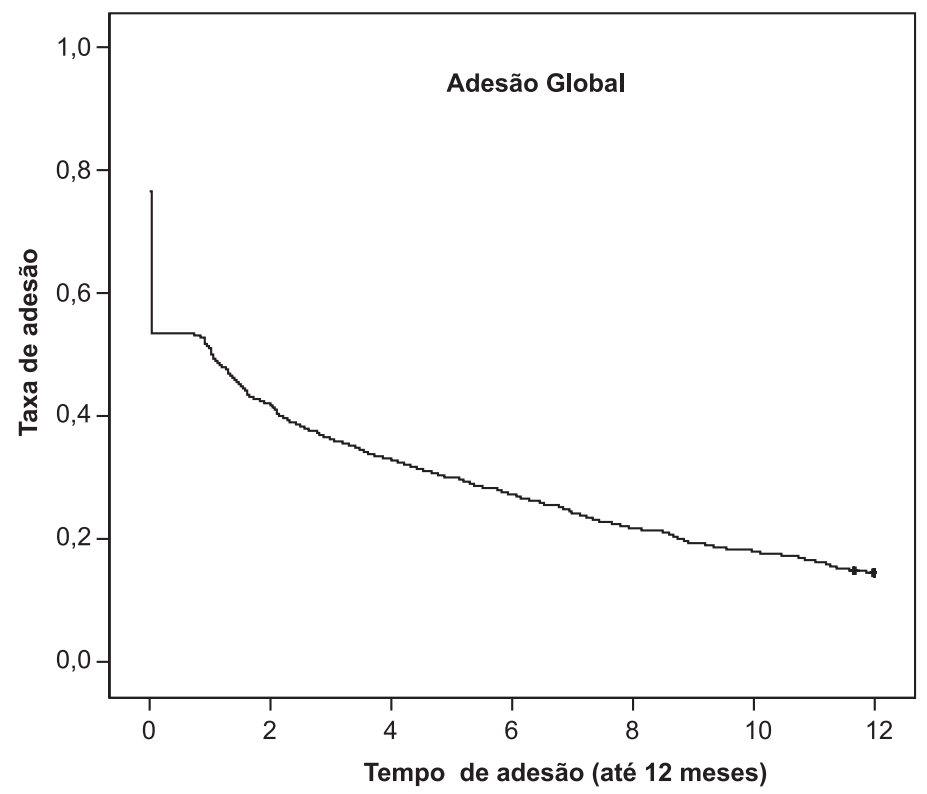

Figura 1 - Curva de continuidade de uso do preservativo feminino segundo o método KaplanMeier, 2008.

Figure 1 - Curves for continuity of use of female condoms, over a 12-month observation period, according to the Kaplan-Meier method, 2008. 
tacts per month were approximately $17 \%$ $\left[(1.0-0.83)^{*} 100\right]$ less likely to abandon the method than those who had 0 to 3 contacts per month;

Women with 4 to 10 sexual contacts per month were approximately $18 \%$ [(1.0 $0.82)^{*} 100$ ] less likely to abandon the method than those with up to 4 sexual contacts per month.

Women from "community project units" were $87 \%$ [(1.0 -0.13$\left.)^{*} 100\right]$ less likely to abandon the method than those in "specialized care" services;

Women in "primary care unit" services were $6 \%\left[(1.0-0.94)^{*} 100\right]$ less likely to abandon than those from "specialized care" services.

The variable color, that in the first Cox model showed association, was identified as a confounding variable.

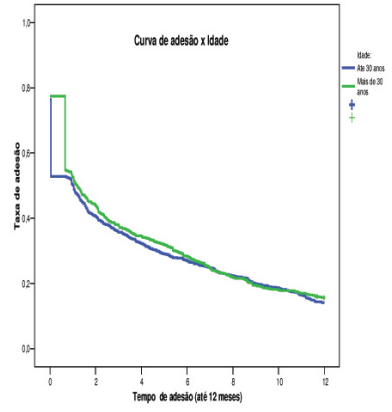

Log-Rank $p=0,317$

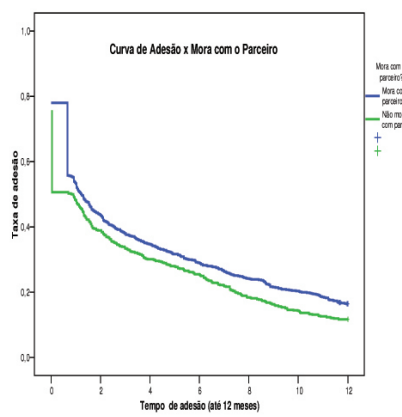

Log-Rank $p=0,003$

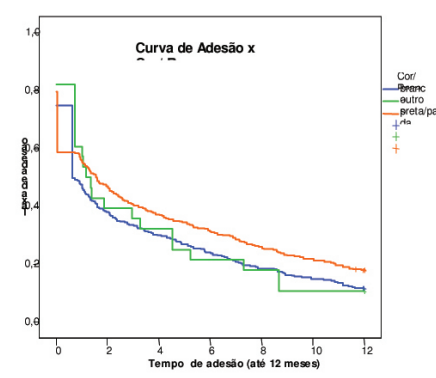

Log-Rank $p<0,001$

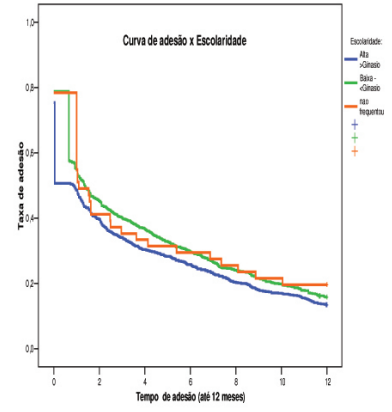

Log-Rank $p=0,035$

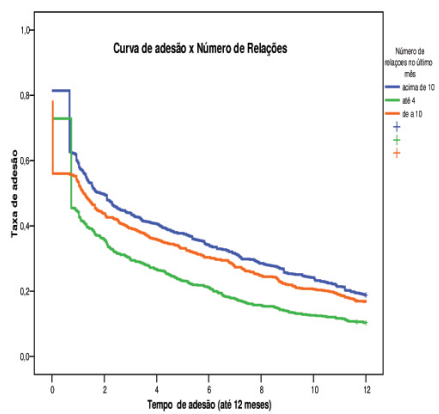

Log-Rank: p-valor $<0,001$

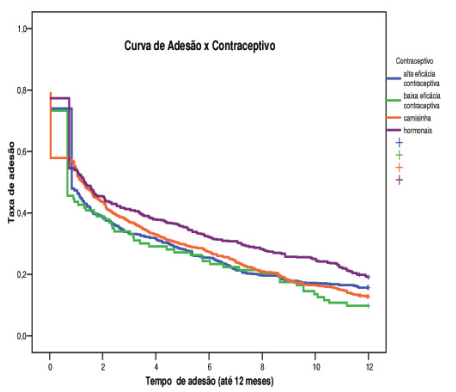

Log-Rank: $p=0,072$

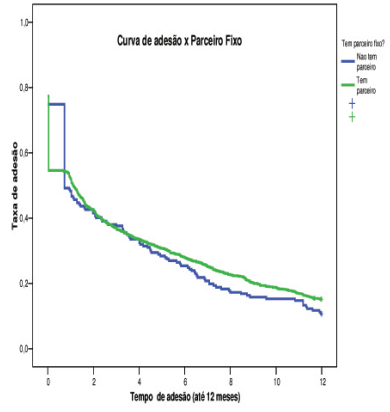

Log-Rank $p=0,168$

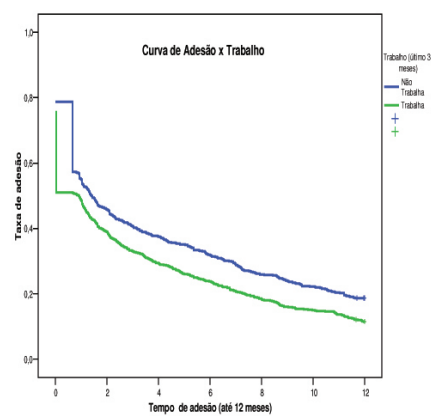

Log-Rank $p<0,001$

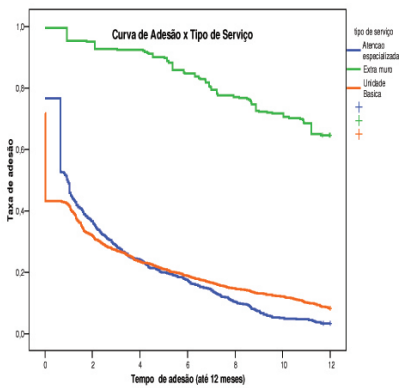

Log-Rank $p<0,001$

Figura 2 - Curvas de continuidade de uso do preservativo feminino (Kaplan-Meier) segundo variáveis selecionadas, 2008.

Figure 2 - Curves for continuity of use of female condoms (Kaplan-Meier), over a 12-month observation period, according to selected variables, 2008. 
Tabela 2 - Análise multivariada de Cox para o tempo de continuidade de uso do preservativo feminino, com exclusão da variável cor, 2008.

Table 2 - Cox multivariate analysis on the duration of continuous use of female condoms, with exclusion of the variable of skin color, 2008.

\begin{tabular}{lccccc}
\hline Variable & Coefficient & p-value & Exp (coef) & Lower Limit & Upper Limit \\
\hline Type - Specialized care & & 0.000 & & & 0.10 \\
Type - Community project & -2.03 & 0.000 & 0.13 & 0.17 \\
Type - Basic unit & -0.06 & 0.240 & 0.94 & 0.85 & 1.04 \\
\# of sexual intercourses/month: 0 to 3 & & 0.001 & & & 0.92 \\
\# of sexual intercourses/month : 4 to 10 & -0.20 & 0.001 & 0.822 & 0.73 & 0.93 \\
\# of sexual intercourses/month: 11+ & -0.19 & 0.001 & 0.826 & 0.73 & 0.93 \\
\hline
\end{tabular}

\section{Discussion}

The present study is pioneer on the female condom, carried out with an expressive number of women who attended public health services of a metropolitan area, according to their own conditions and routines.

There is predominance in the literature of studies that refer to specific population groups, such as: sex workers ${ }^{13,14}$, students ${ }^{15}$, health professionals ${ }^{16}$, users of family planning clinics $^{17}$, STD clinic users ${ }^{18}$, adolescents $^{19}$, and refugees ${ }^{20}$. Others were developed in partnerships with feminist or feminist coordinated NGOs ${ }^{8}$.

There are few studies with greater diversity of sample recruitment sites and with direct involvement of health system programs/managers ${ }^{21,22}$.

The method adopted, choosing to work with dispensation units of organizational structures and different missions, in partnership with local, municipal and state health managers, allowed closer approximation to actual offer and support conditions to continue use, and more diversity of participants.

Given it is a study performed in routine conditions of services, its development was subject to the limitations that referred to the variability of technical-operational conditions and their management during the study period.

It was not possible to assess the consistency of use, because it would then require a sexual diary, in which participants would take notes, upon each sexual intercourse, if any protection was used, specifying if it was a female or male condom. This would demand greater investment and control and, therefore, greater interference in the process $^{10}$. An indicator was pursued toward that end, with the question "which protection was adopted in the last sexual intercourse?", intended to be asked at each follow-up visit. The question was not filled out uniformly, however, with a very high rate of non response, which prevented its analysis.

Results on initial demand at all services indicate that women are willing to know new alternatives that avoid non desired pregnancy and do not yield side effects, which is understandable given the limited range of contraceptive options in Brazill ${ }^{23}$. They search for possibilities that also provide protection against STDs/AIDS (double protection $)^{24}$, showing that if it is made available by health services, there will be segments of the population willing to adopt it, similar to what is being reported throughout the world ${ }^{6,7,8,18,19,20,21,22}$.

The continuity of use rates detected in the present study (36.5\% in the third month, $27.3 \%$ in the sixth and $14.4 \%$ at the end of 12 months of observation), correspond to average figures found in the literature, that report immediate acceptance rates, up to 6 months, that vary from $37 \%$ to $96 \%$ of those who begin use ${ }^{6,7,8,21}$.

The proportions of use were similar to 
those observed for other methods. Ferraz ${ }^{25}$, in one of the few studies on the dynamics of use of contraceptives in Brazil, observed that the median use of male condom was 1.8 months and of 3.9 months for injectables in women of the Northeast. Leite et al. ${ }^{26}$ also observed high discontinuity, given only $20 \%$, $30 \%$ and $42 \%$ kept using male condoms, injectables and the pill, respectively, in 12 months.

The high discontinuity of use in the first month among users of specialized services and of primary care units corroborates what experts have been affirming for decades: the initial months are critical to maintain a method, especially those who demand change in behavior and are coitus dependent, given in this period women (and/or couple) confront information and expectations to the reality of their daily lives ${ }^{27}$.

Studies have revealed that $35 \%$ to $50 \%$ of users of female condom have faced difficulties of insertion in initial experiences ${ }^{7,8}$. Such findings strengthen the need that users find support at services to solve their difficulties in the adaptation period, whether for maintenance or change of method.

The contraceptive method adopted did not show association with the use of female condom, because continuity rates among women who did not need to avoid pregnancy (tubal ligation, hysterectomy, partners of vasectomy and menopausal) and users of hormone contraceptives and male condoms) were not shown to be statistically different. The lower adherence rate among women who adopted low efficacy practices (regular abstinence and withdrawal method) stands out, suggesting that it is more difficult for them to incorporate any practice and/or input regularly, and that they therefore should get differentiated guidance and support.

Women with more frequent sexual relations showed significant longer use. Having two types of condoms probably increased the number of protected sexual intercourse, because literature data consider that when there are more alternatives available that enable changes, couples are more likely to use protection. Several authors have reported that access to female condoms, along with the male ones, significantly increase the proportion of protected sexual relations. Witte et al. ${ }^{14}$ in a study performed in New York, made input available to participants, forming three groups: the first received male condoms, the second, only female condoms, the third, both. There was higher reduction in non protected relations in the group that received both methods, followed by the one that received female condoms. The same was observed by Musaba et al. ${ }^{18}$ in a study developed in Zambia with 99 couples with STDs.

The kind of service, consequent to the way the links among providers and users establish, was determinant of continuity of use.

In community project units, the proportion of women who continued using the method was considerably higher $(83.8 \%$ in the sixth month and $64.6 \%$ at the end) than at primary health care units $(18.8 \%$ in the sixth month and $8.27 \%$ at the end) and than at specialized services $(17.7 \%$ in the sixth month and $3.4 \%$ at endpoint). It should be pointed out that participants began knowing the female condom only upon entry in the study, so information on the method, how to handle it and alternatives to face adaptation difficulties were conveyed exclusively by dispensation units. At community project units, interventions were conducted by community leaders, peer groups, which have been documented, from the initial studies on the method, as the most effective educational method. Ray and Maposhere ${ }^{13}$ in a study with two groups of sex workers in Zimbabwe, verified that the group trained by peers presented higher proportion of use, showing greater skills to negotiate with clients, than the group trained by health professionals, despite the high initial acceptance of both groups.

The influence of educational activities toward more adherence to the method has been reported by several authors. Barbosa et al. ${ }^{21}$ observed similar proportions of continuity of use, at 90 days, from $54 \%, 68 \%$ 
and $78 \%$, a statistically significant difference, for services with incipient educational activities, with experience in educational activities for women and for those that, in addition to tradition in women-oriented educational activities, carried out outreach work, respectively.

The same was observed in South Africa, where despite the availability of the input for years at the University Clinic, it was not being used by university students. Zondi et al. ${ }^{28}$ carried out focus groups with students (women and men) to understand the issue and concluded that the main impediments were: lack of information on the method and where to find it, along with the bad impression caused by its appearance. Students considered educational activities as fundamental "to feel liking using it".

Morrisey et al. ${ }^{29}$ identified, based on 82 interviews with women health provider services in New York, that health professionals attitudes were one of the determining factors for low adherence to the method. They considered it a negative influence upon the way women choose contraceptive methods and prevent diseases.

At community project units, many of the men who asked for educational activity oriented toward them were not partners of female condom users. The answer to the request was an intervention in which several aspects of sexuality were discussed. Such fact suggests that the information/guidance given to women was circulating among dwellers, which must have also contributed to the greater adherence observed, as a favorable environment has been appointed as an important factor toward the success of interventions that demand behavior changes $^{30}$.

In summary, the results reaffirm the need to invest in creating awareness and building skills of health professionals in order to prevent the possible influence exerted by them, according to the World Health Organization, that inhibit with their behavior potential users/users of barrier methods, such as condoms ${ }^{30}$.

It is not a question of only teaching how to handle the method, it is fundamental to provide conditions for other aspects of affective and sexual life to emerge, so they may be discussed and thought about by users and health professionals and that all contraceptive alternatives be presented, so that users decide what is best for their lives at the time.

Therefore, it is not only a matter of assessing/making female condoms available, but of re-discussing what is being appointed for two decades by activist researchers who work with women, including the Comprehensive Women's Health Care Program - PAISM, that is, to provide comprehensive care to women ${ }^{8,31}$.

The basic question is not if they liked or used the female condom, but how to create awareness and provide tools to professionals and restructure services, especially primary health care units - PSF, so they can listen and give appropriate answers to women, and if women desire, provide conditions for sustained use. It is not just this particular input, but all of them, as several authors have already reported ${ }^{21,31}, 32$.

The offer of female condoms is still very restricted, but there are however domestic and international initiatives to expand it, and make it more adequate, anatomical and with a better aspect, and at a lower cost. However, with the expanded offer of the method the SUS will face a huge challenge, because as results have showed, in addition to making the method available, it is basic to plan appropriate awareness creation and training for professionals that work in health services, especially primary healthcare units so that female condoms may be a concrete alternative to women. 


\section{References}

1. Ministério da Saúde. Coordenação Nacional de DST/ Aids. Boletim Epidemiológico AIDS/DST. Brasília (DF); 2005.

2. Bastos FI, Hacker MA. Pesquisas brasileiras psicossociais e operacionais face às metas da UNGASS. Rev Saúde Pública 2006; 40(S): 42-51.

3. Berer M, Ray S. Women and HIVIAIDS: an international resource book. London: Reproductive Health Matters and AHRTAG; 1993.

4. Saffioti HIB. Rearticulando gênero e classe social. In: Costa AO, Bruschini C (org.). Uma questão de gênero. Rio de Janeiro/São Paulo: Rosa dos Tempos/Fundação Carlos Chagas; 1992: 183-215.

5. Quinn SC. AIDS and the african american woman: The triple burden of race, class and gender. Health Educ Q 1993; 20(3): 305-20.

6. World Health Organization - WHO. The Female condom: a Review. Geneva; 1997.

7. Hoffman S, Mantell J, Exner T, Stein Z. Viewpoints: The future of the female condom. Perspect Sex Reprod Health 2004; 36(3): 120-6.

8. Kalckmann S, Rea M, Villela WV, Vieira EM, Fernandes MEL, Ankrah M. Female condom: Exploratory study in São Paulo. Int Conf AIDS. 1998; 12: 434 (abstract no. 23460) Genebra. Available at: http://gateway.nlm.nih. gov/MeetingAbstracts/ma?f=102229088.html

9. Kalckmann S, Barboza R, Barbosa RM, Arantagy AM. Desafios e avanços: monitoramento da implantação do preservativo feminino no estado de São Paulo. In: I Fórum e II Conferência de cooperação técnica da América Latina e do Caribe em HIVIAids e DSAT. Rio de Janeiro. Brasil. Ministério da Saúde; 2000; II: 761.

10. World Health Organization - WHO. Health Programmes Evaluation. Genebra; 1991.

11. Rumeau-Rouquette C, Breart G, Padieu R. Méthodes em Epidemiologie. Paris: Flammarion; 1994.

12. Kleinbaum DG, Kupper LL, Morgenstern H. Epidemiologic research - Principles and quantitative methods. New York: Van Nostrand Reinhold Press; 1982.

13. Ray S, Maposhere C. Male and female condom use by sex workers in Zimbabwe: acceptability and obstacles. In: Beyond acceptability: user's perspectives on contraception. Compiled by World Health Organization (WHO), Reprod Health Matters. London, England; 1997. pp. 97-108.

14. Witte SS, el-Bassel N, Wada T, Gray O, Wallace J. Acceptability of female condom use among women exchanging street sex in New York City. Int J STD AIDS 1999; 10(3): 162-8.
15. Angulo A, Meischke H, Gonzales V, Garcia PJ. Determinants of female condom preference among young, heterosexual women in Lima, Peru. In: Anais XVI International AIDS Conference; 2006; Toronto, Canadá. (MOPE0782). Available at: http://www.iasociety.org/ default.aspx?pageId=11\&abstractId $=2189972$

16. Gollub EL, Stein Z, El-Sadr W. Short-term acceptability of the female condom among staff and patients at a New York City hospital. Int Fam Plan Perspect 1995; 27(4):1558.

17. Adeokun L, Mantell JE, Weiss E, Delano GE, Jagha T, Jumoke T et al. Promoting dual protection in family planning clinics in Ibadan, Nigeria. Int Fam Plan Perspect 2002; 28(2): 87-95.

18. Musaba E, Morrison CS, Sumkutu MR, Wong EL. Longterm use of the female condom among couples at high risk of human immunodeficiency virus infection in Zambia. Sex Transm Dis 1998; 25(5): 260-4.

19. Haignere CS, Gold R, Maskovsky MAJ, Ambrosini JBA, Rogers PAC, Gollub E. High-risk adolescents and female condoms: knowledge, attitudes and use patterns. $J$ Adolescent Health 2000; 26: 392-8.

20. Papo J, Schilperoord M. Promoting the female condom in the refugee setting. In: Anais XVI International AIDS Conference; 2006; Toronto, Canadá. (TUPE0378). Available at: http:/ / www.iasociety.org/Default.aspx?pag eId=11\&abstractId=2198469

21. Barbosa RM, Kalckmann S, Berquó E, Stein Z. Notes on the female condom: experiences in Brazil. Int J STD AIDS 2007; 18: 261-6.

22. Mantell JE, Scheepers E, Abdool Karim Q. Introducing the female condom through the public health sector: Experiences from South Africa. AIDS Care 2000; 12(5): 589-601.

23. Costa AM, Guilhem D, Silver LD. Planejamento familiar: a autonomia das mulheres sob questão. Rev Bras Saúde Matern Infant 2006; 6(1): 75-84.

24. Berer M. Dupla proteção: mais necessária do que praticada ou compreendida. Questões de Saúde Reprodutiva 2007; 2(2): 23-33.

25. Ferraz EA. Dinâmica do uso da anticoncepção na região Nordeste do Brasil: uma análise de descontinuação, falha e mudança de métodos com tábuas de mortalidade. In: Fecundidade, anticoncepção e mortalidade infantil: pesquisa sobre saúde familiar no Nordeste 1991. Rio de Janeiro: BEMFAM - Sociedade Civil Bem-Estar Familiar no Brasil/Demographic and Health Surveys; 1994. pp. 93-112.

26. Leite IC. Descontinuação de métodos anticoncepcionais no Nordeste do Brasil, 1986-1991. Cad Saúde Pública 2003; 19(4): 1005-16. 
27. Tietze C. The clinical effectiness of contraceptive methods. Am J Obst Gynaecol 1959; 78: 650-6.

28. Zondi S, Adams-Skinner J, Mthembu N, Mantell J, Smit J, Mabude Z et al. Exploring knowledge, attitudes and practices about the female condom among South African male tertiary students: findings from focus group discussions. In: Anais XVI International AIDS Conference; 2006; Toronto. Canadá. (CDC0827). Available at: http://www.iasociety.org/ default.aspx?pag eId=11\&abstractId=2197321 .

29. Morrissey KL, Mantell JE, Hoffman S, Exner TM, Pili C, Brothers LP, Lee JY. I think it works, but I wouldn't recommend it: NYC health care providers' views on the efficacy and feasibility of the female condom. In: Anais The XIV International AIDS Conference; 2002 ; Barcelona. Espanha. (MoPeF3878). Available at:http://www.iasociety.org/Default.aspx? pageId $=11$ \&abstractId $=4255$.
30. World Health Organization/ UNAIDS. The female condom: a guide for planning and programming. Geneve: WHO/UNAIDS; 2000. Available at: http://www. who.int/ reproductive-health/publications/RHR_00_8/.

31. Askew I, Berer M A. Contribuição dos serviços de saúde reprodutiva e sexual à luta contra o HIV/Aids: uma revisão. Questões de saúde reprodutiva 2006; I(1): 11-38.

32. Ministério da Saúde. Coordenação Nacional de DST/ Aids. Adoção de Práticas sexuais mais seguras entre mulheres - Intervenções educativas com o preservativo feminino. Relatório de pesquisa. Brasília (DF); 2005. 